\title{
Properties of composite materials absorbing electromagnetic waves on the styrene-butadiene-styrene copolymer matrix with EMCCO-201 filler
}

\author{
Andrzej $\operatorname{Vogt}^{1)}$, Jacek W. Kaczmar ${ }^{2)}$, Paulina Mayer*), 2), Aleksandra Brzostek ${ }^{2)}$, Leszek Nowosielski ${ }^{3)}$, \\ Rafał Przesmycki ${ }^{3)}$
}

DOI: dx.doi.org/10.14314/polimery.2020.7.6

\begin{abstract}
In this paper, a manufacturing method for composite materials that absorb electromagnetic waves in the form of blends of EMCCO-201 with SBS (styrene-butadiene-styrene copolymer, trade name Kraton) is shown and the absorption characteristics of the prepared samples are discussed. The materials were manufactured on the basis of extrusion technology. The absorption characteristics of the tested materials were measured as a function of the testing signal angles of incidence. The samples were $300 \times 300 \mathrm{~mm}$, made of aluminum alloy sheet and covered with either absorption elements that were spheroids of diameters 1-2 mm and 3-4 mm made of $50 \mathrm{vol}$. \% of EMCCO-201 with SBS (styrenebutadiene-styrene) copolymer or pyramids with a $25 \times 25 \mathrm{~mm}$ base and height of $50 \mathrm{~mm}$ made of epoxy resin covered by spraying with a layer of EMCCO-201 material without SBS copolymer. Absorption measurements were carried out in the frequency range from 3.0 to $11.0 \mathrm{GHz}$. The largest absorption of $5.5-6.0 \mathrm{~dB}$ at the frequency range of 7.0-10.0 GHz was obtained for samples with the epoxy resin pyramids of a square base $25 \times 25 \mathrm{~mm}$ and height of $50 \mathrm{~mm}$ covered with a layer of EMCCO-201 material. The samples with the spheroids showed smaller absorption between 1-3 dB at the same frequency range.
\end{abstract}

Keywords: electromagnetic waves absorbing materials, absorption measurements, absorbing layers.

\section{Właściwości materiałów kompozytowych na bazie kopolimeru styren-butadien-styren napełnionego EMCCO-201 absorbujących fale elektromagnetyczne}

Streszczenie: Przedstawiono metodę wytwarzania kompozytów absorbujących fale elektromagnetycz-
ne w postaci mieszanek materiału absorbującego typu EMCCO-201 z kopolimerem SBS (styren-buta-
dien-syren, nazwa handlowa Kraton). Materiały kompozytowe otrzymywano metodą wytłaczania.
Charakterystykę absorpcji badanych materiałów wyznaczano przy użyciu próbek blachy o wymiarach
$300 \times 300 \mathrm{~mm}$ ze stopu aluminium, pokrytej elementami absorbującymi w postaci sferoidów wyko-
nanych z kompozytu kopolimeru SBS zawierającego $50 \%$ obj. EMCCO-201, o średnicach $1-2 \mathrm{~mm}$ oraz
$3-4 \mathrm{~mm}$, a także w postaci ostrosłupów charakteryzujących się podstawą o wymiarach $25 \times 25 \mathrm{~mm}$
i wysokością $50 \mathrm{~mm}$ wykonanych z żywicy epoksydowej, pokrytych warstwą materiału EMCCO-201
bez kopolimeru SBS. Pomiary absorpcji fal elektromagnetycznych przeprowadzono w zakresie często-
tliwości od 3.0 do $11.0 \mathrm{GHz}$. Największą absorbcją $5-6 \mathrm{~dB}$ w zakresie 7.0-10.0 GHz charakteryzowały
się próbki z elementami tłumiącymi w kształcie ostrosłupów o podstawie kwadratowej $25 \times 25 \mathrm{~mm}$
i wysokości 50 mm wykonanymi z żywicy epoksydowej i pokrytymi materiałem EMCCO-201. Próbki
z elementami tłumiącymi w formie sferoidów charakteryzowały się małą absorbcją o wielkości $1-3 \mathrm{~dB}$
w analogicznym zakresie częstotliwości.

Słowa kluczowe: materiały absorbujące fale elektromagnetyczne, pomiary absorpcji, warstwy absorbujące.

\footnotetext{
1) University of Wroclaw, Department of Chemistry, Fryderyka Joliot-Curie 14, 50-383 Wroclaw, Poland.

2) Wroclaw University of Technology, Department of Lightweight Elements Engineering, Foundry and Automation, Wybrzeże Stanisława Wyspiańskiego 27, 50-370 Wroclaw, Poland.

3) Military University of Technology, Faculty of Electronics, gen. Sylwestra Kaliskiego 2, 00-908 Warszawa 00-908 Warsaw, Poland.

*) Author for correspondence: paulina.mayer@pwr.edu.pl
} 
Materials absorbing electromagnetic waves reduce the energy of electromagnetic radiation generated by household electrical appliances. These materials are also important for military applications where they reduce the Radar Cross Section (RCS), thus diminishing the possibility of detecting military objects like airplanes or ships. The most commonly applied material for the absorption of electromagnetic energy is a mixture of ferrite and carbon black. There are new materials in continuous development that are characterized by better absorption properties than conventional ferrite based materials.

Che et al. [1] prepared epoxy nanocomposite/multiwalled carbon nanotubes (MWCNTs) by two methods. The composite materials with very low MWCNTs contents (0.25-0.5 wt \%) and small matching thickness (2-3) $\mathrm{mm}$ showed relatively good microwave absorption properties. For instance, a layer of composite material with the addition of 0.25 wt \% MWCNTs and thickness of $2 \mathrm{~mm}$ prepared by the dispersion method was characterized by a reflection loss above $10 \mathrm{~dB}$ in a wide frequency range of $8.5-11.4 \mathrm{GHz}$ with a maximum peak of $21.5 \mathrm{~dB}$. Zakharychev et al. [2] also used carbon nanotubes in order to produce composite materials with epoxy resin matrix. The absorption properties of the samples were measured in the frequency range of 5.2-7.3 GHz. They calculated the reflection coefficient $\left(K_{\text {reff }}\right)$ in the air - RAM (Radar Absorbing Materials) interface and the absorption coefficient $\left(K_{\mathrm{abs}}\right)$. The investigations showed good absorption results for composite materials containing nanotubes of diameter 8-15 nm and length of $2 \mu \mathrm{m}$.

Chen et al. [3] manufactured a hybrid three-dimensional absorber based on reduced graphene oxide (rGO) and multi-walled carbon nanotubes - rGO/MWCNTs. Its' properties were compared with a three-dimensional absorber based on graphene nanoplatinum (GNPs, graphene nanoplatelets) - GNPs/MWCNTs produced in the same way. The tests of the dielectric properties were carried out in the frequency range from $8.4 \mathrm{GHz}$ to $12.0 \mathrm{GHz}$. The highest loss of reflectivity $(R L)$ for an absorber based on rGO/MWCNTs was $41 \mathrm{~dB}$ at $9.6 \mathrm{GHz}$. For the absorber based on GNPs/MWCNTs, the highest $R L$ value of $23 \mathrm{~dB}$ was observed for the $8.4 \mathrm{GHz}$ frequency.

Zhao et al. [4] produced a composite absorber with a sandwich microstructure based on expanded graphite (EG) and barium ferrite $\mathrm{BaFe}_{12} \mathrm{O}_{19}(\mathrm{BF})$ with the addition of carbon nanotubes (CNTs). Composite materials with paraffin as the matrix were prepared for the production of absorbers for testing (the paraffin content was $75 \mathrm{wt} \%$ ) The lowest $R L$

Of $49.5 \mathrm{~dB}$ at a frequency of $11.2 \mathrm{GHz}$ was observed for absorber CNT/EG/BF with a layer thickness of $1.5 \mathrm{~mm}$.

Liu et al. [5] investigated the properties of a two-layer absorber based on a ferrite based composite material $\mathrm{Co}_{0.2} \mathrm{Ni}_{0.4} \mathrm{Zn}_{0.4} \mathrm{Fe}_{2} \mathrm{O}_{4}(\mathrm{CNZF})$ and reduced graphene oxide (rGO). The individual composite layers were prepared by mixing $30 \mathrm{wt} \% \mathrm{CNZF}$ with paraffin and $30 \mathrm{wt} \%$ of rGO with paraffin separately. The microwave absorp- tion properties depended on the thickness of the individual layers. The CNZF layer was characterized by a high impedance matching ratio, while the rGO layer has a large dielectric loss.

Gholampour et al., [6] focused on the production of $\mathrm{Fe}_{3} \mathrm{O}_{4}$ nanoparticles and the study of the effect of their structure on the properties of the electromagnetic wave absorption. A three-dimensional structure of nanoparticles on a carbon fiber backbone (CFs) was prepared. The dielectric and magnetic losses for the tested composite materials were determined in the frequency range 8.2-12.2 GHz. The highest $R L$ was recorded for a sample with a thickness of $2 \mathrm{~mm}$ at $10.1 \mathrm{GHz}$, which was $10.2 \mathrm{~dB}$.

Other sandwich structure microwave absorbing structures (SSMASs) derived from Salisbury type absorbers were reported by Liu et al. [7]. The microwave absorption properties of SSMASs were measured and then compared with the results obtained from computer simulations. The experimental and computer simulation results were in good agreement and for the SSMASs they can reach the bandwidth of reflectivity below $10 \mathrm{~dB}$ at a frequency of $11.6 \mathrm{GHz}$.

Liu et al. [8] manufactured materials absorbing electromagnetic waves with single-layer and double-layer composite materials based on carbonyl iron powder (CI) and $\mathrm{CoFe}_{2} \mathrm{O}_{4}$ ferrite. The electromagnetic transmission line theory and the impedance matching principle in the frequency range from $2.0 \mathrm{GHz}$ to $18.0 \mathrm{GHz}$ was applied to check the microwave absorption. Double-layer absorbers have much better microwave absorption properties than single-layer absorbers. The double-layer microwave absorbers with a reflection loss less than $10 \mathrm{~dB}$ over the frequency range from $8.6 \mathrm{GHz}$ to $18 \mathrm{GHz}$ (the absorption bandwidth is $9.4 \mathrm{GHz}$ ), which almost covers the X-band 8.2-12.4 GHz and the whole Ku-band 12.4-18.0 GHz were achieved for the thicknesses of $\mathrm{CoFe}_{2} \mathrm{O}_{4}$ and CI of $2.4 \mathrm{~mm}$ and $0.5 \mathrm{~mm}$, respectively.

The triple-layered composite materials reinforced with multi-walled nanotubes (MWNTs) dispersed in an epoxy/cotton fabric resistive layer placed between two MWNTs filled E-glass fiber/epoxy dielectric absorbing layers were manufactured by Choi et al. [9]. The measurements showed that the sandwich, triple-layered structure shows an outstandingly broad bandwidth of reflection loss below $10 \mathrm{~dB}$ from $4.7 \mathrm{GHz}$ to $13.7 \mathrm{GHz}$ and a maximum reflection loss peak of $22.3 \mathrm{~dB}$ at $11.8 \mathrm{GHz}$ frequency.

Zhang et al. [10] applied the molten salt method for the manufacture of epsilon- $\mathrm{Fe}_{3} \mathrm{~N}$ powders characterized by a hexagonal structure. The maximum reflection loss of the epsilon- $\mathrm{Fe}_{3} \mathrm{~N} /$ epoxy composite was $7.6 \mathrm{~dB}$ at $7.28 \mathrm{GHz}$ for a layer thickness of $2 \mathrm{~mm}$.

Kumar et al. [11] manufactured two types of sandwich structures as radar absorption materials applied for stealth technology. The reference sandwich material consisted of the following layers: E-glass/epoxy, PVC [poly(vinyl chloride)] foam or balsa wood, FSS 
(Frequency Selective Surface), composite face. Six types of sandwich structures materials were tested, which had different configurations and number of individual layers. All manufactured composite radar wave absorption structures required conditions for stealth applications, namely: were characterized by more than $80 \%$ of transmission rate, by less than $1 \mathrm{GHz}$ of the bandwidth for $1 \mathrm{~dB}$, by resonance in the $\mathrm{X}$-band frequency range and by relatively high mechanical flexural strength.

Wang et al. [12] elaborated the electromagnetic wave absorption materials as sheets based on epoxy composites reinforced with Ag-coated hollow glass spheres (HGS@Ag) and a small quantity of graphene (rGOreduced graphene oxide). Seven different materials were measured by a vector network analyzer via the reflection/transmission method in the frequency range 1-18 GHz. The samples were characterized for various thicknesses between $2-3.5 \mathrm{~mm}$. The maximum reflection loss achieved was $46.1 \mathrm{~dB}$ at the $11 \mathrm{GHz}$ frequency for 50 wt \% HGS@Ag and 1wt \% rGO in epoxy composites with a thickness of $2 \mathrm{~mm}$.

The aim of this work was to develop new composite materials composed of a mixture of EMCCO-201 material and SBS copolymer (Kraton) characterized by the good forming ability and homogeneous distribution of both components, simultaneously showing good absorption properties of electromagnetic wave energies. The manufacturing of these materials was performed at the Laboratory of Polymers at the Wroclaw University of Science and Technology and Faculty of Chemistry of Wroclaw University. The authors focused on the manufacturing of spatial structures and the comparison of their absorption properties to the properties of flat materials. The measurements of attenuation were carried out in the anechoic chamber located at the Laboratory of Electromagnetic Compatibility, Faculty of Electronics, Military University of Technology in Warsaw.

\section{EXPERIMENTAL PART}

\section{Materials}

The materials for the attenuation of electromagnetic waves were manufactured from a mixture of absorption material EMCCO-201 (present name REC-n, delivered by the company Ferristorm S.A., Poland) and SBS copolymer (trade name Kraton). Composite EMCCO-201 material was invented at the Department of Chemistry, University of Wroclaw by Prof. Hubert Kołodziej, Dr. Andrzej Vogt, Dr. Andrzej Sowa and Eng. Stanislaw Strzelecki and is described in UK Pat. Reg. Nr. 375/34UK/2000 [13]. The new composite material was described in [14, 15], and its application in [16]. This material belongs to the new generation of materials showing very good absorption properties of electromagnetic waves in a very wide band of frequencies. Composite material EMCCO-201 shows a synergistic effect in relation to the integrated magnetic permeability.
Its magnetic permeability and magnetic losses are significantly larger than for the components forming the final product. The most simple materials of this type contains two components and the most complex six components. To the main components belong: FF-n (ferrimagnetic), magnetic material (ferritic powder), elastomer, plasticizer, and synergistic factor of the electric component.

SBS copolymers (Kraton) structurally consist of a three block copolymer styrene/butadiene/styrene (SBS) characterized by a linear structure. The main chain of SBS copolymer consists of two hard blocks of styrene and a soft block of butadiene [Formula (I)]. SBS copolymer (Kraton) can be processed by conventional methods. The mixing process of SBS copolymer with EMCCO-201 should ensure the homogeneous mixture of components, reproducible properties and minimum gravity segregation. Inhomogeneous mixtures can cause the loss of mechanical and absorption properties.

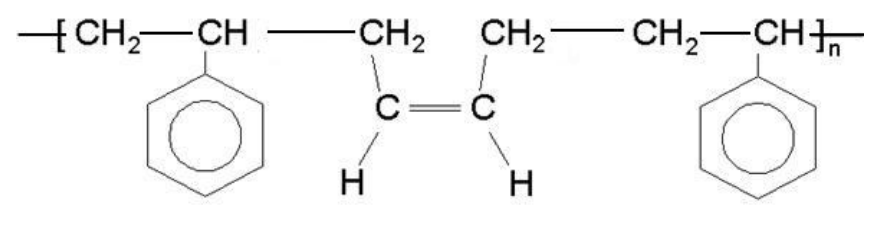

(I)

The mixtures of EMCCO-201 and Kraton elastomere contained: 10, 20, 40 and 50 vol. \% of absorption material and were manufactured in the 1-worm extruder, applying the extrusion head working at $140^{\circ} \mathrm{C}$ for the manufacturing of a cylindrical shaped product. According to the fact that the mixtures of EMCCO-201 with Kraton containing 10-40 vol. \% of EMCCO-201 showed relative small attenuation of the electromagnetic waves, thus for further investigations, material containing $50 \mathrm{vol}$ \% of EMCCO-201 was chosen.

\section{Preparation of samples}

From the manufactured material - a mixture of Kraton and 50 vol. \% of EMCCO-201 materials were produced with ovalization into two sizes of spheroidal particles:

- characterized by diameters of 1-2 $\mathrm{mm}$,

- characterized by diameters of 3-4 $\mathrm{mm}$.

The spheroidal particles from the mixture of Kraton with 50 vol. \% of EMCCO-201 material were manufactured by cutting extruded materials and pressing them into balls by applying shaped dies and punches. The final ovalization was performed in a designed device with a rotating plate. The selection of the sizes 1-2 mm and 3-4 mm was performed with the help of sieve analysis. Finally, spheroidal particles of the absorber (50 vol. \% of EMCCO-201 with Kraton) were pasted to base plates of $300 \times 300 \times 1 \mathrm{~mm}$ made of the 6061 aluminum alloy. Epoxy glue (Loctite EA 3450) was used to join the manufactured composite material to the aluminum plate. 


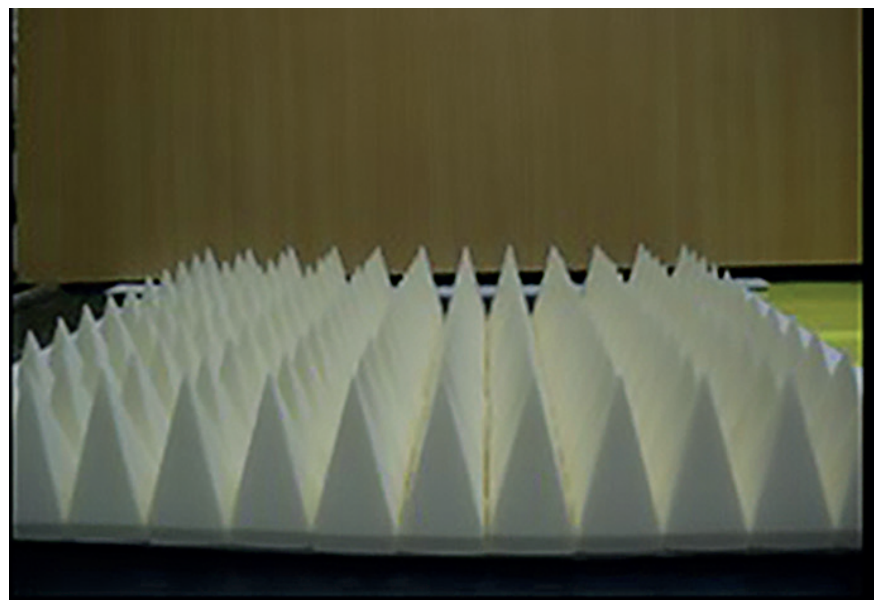

Fig. 1. Pyramid-shaped elements made of epoxy resin attached to the 6061 aluminum plate

Moreover, there were manufactured pyramid-shaped elements characterized by a square base of $25 \times 25 \mathrm{~mm}$ and height of $50 \mathrm{~mm}$ prepared by casting epoxy resin (Epidian 652 and IDA hardener delivered by CIECH Sarzyna S.A.) into flexible forms. The pyramids were fastened to a square of 6061 aluminum plate of $300 \times 300 \times 1 \mathrm{~mm}$ size and Fig. 1 shows the pyramids before the process of their covering with a layer of EMCCO-201 material.

All samples for the investigations were square samples of a side $300 \mathrm{~mm}$ made of 6061 aluminum sheet with attached suitable absorption elements like spheroidal particles or pyramids. As the reference sample, a square with a side of $300 \mathrm{~mm}$ made from a sheet of low carbon steel for cold forming of DC01 type $(0.12 \%$ C, $0.60 \% \mathrm{Mn}, 0.045 \% \mathrm{P}$ and $0.045 \% \mathrm{~S}$ ) was chosen. The pyramids made of epoxy resin were fastened to the 6061 aluminum sheet and covered with the EMCCO-201 absorption material by spray-
$\mathrm{T}$ a b l e 1. Determination and description of the samples

\begin{tabular}{c|c}
\hline $\begin{array}{c}\text { Determination } \\
\text { of samples }\end{array}$ & Description of samples \\
\hline Sample No. 0 & $\begin{array}{c}\text { A metal plate from DC01 steel sheet without } \\
\text { added absorption material (reference material) } \\
\text { A } 6061 \mathrm{Al} \text { alloy plate covered with }\end{array}$ \\
Sample No. 1 & $\begin{array}{c}\text { A } 6061 \mathrm{Al} \text { alloy plate covered with } \\
\text { a polypropylene layer } \\
\text { characterized by spheroidal particles of 1-2 mm }\end{array}$ \\
Sample No. 3 2 & $\begin{array}{c}\text { A 6061 Al alloy plate covered with } \\
\text { a polypropylene layer and absorption material } \\
\text { characterized by spheroidal particles of 3-4 mm } \\
\text { A 6061 aluminum plate with pyramids made of } \\
\text { epoxy resin and covered by spraying with the } \\
\text { material EMCCO-201 }\end{array}$ \\
\hline
\end{tabular}

ing. During spraying, constant stirring of the EMCCO201 absorption material in a suitable solvent (toluene) was applied in order to keep a uniform distribution of this material in the solvent and to avoid gravity segregation. The thickness of the sprayed layer was $100-150 \mu \mathrm{m}$. The samples prepared for the attenuation measurements are shown in Fig. 2 and described in Table 1.

\section{Methods of testing}

The absorption measure was the signal level difference between the probe signal level in $\mathrm{dB}$ reflected from the metal plate not covered and covered by the different forms of absorption materials [17-20]. This is a measure of field strength of the electromagnetic wave absorbed by the different forms of materials fastened to the Al-plates. The presented measurement procedure requires two flat
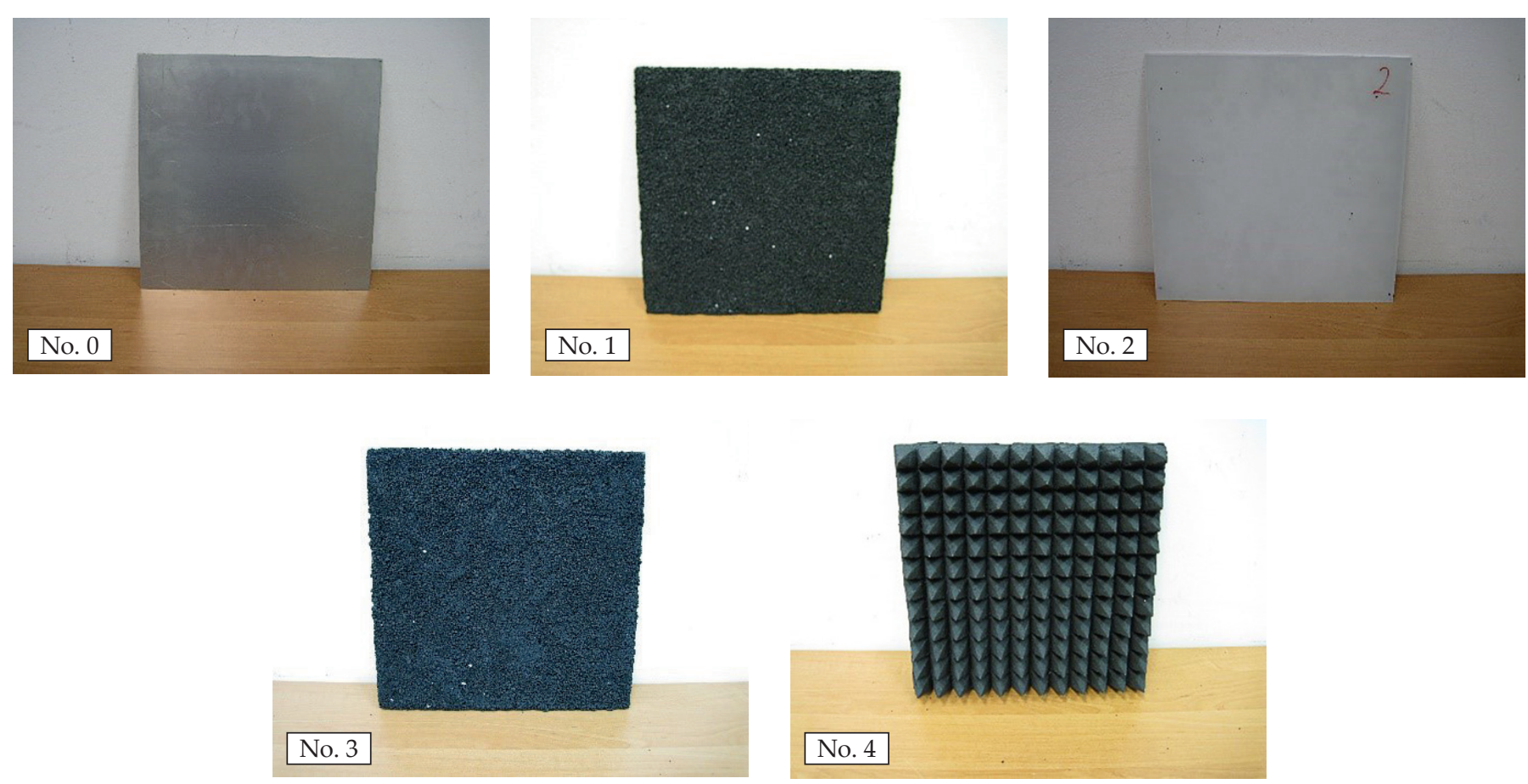

Fig. 2. The test samples 


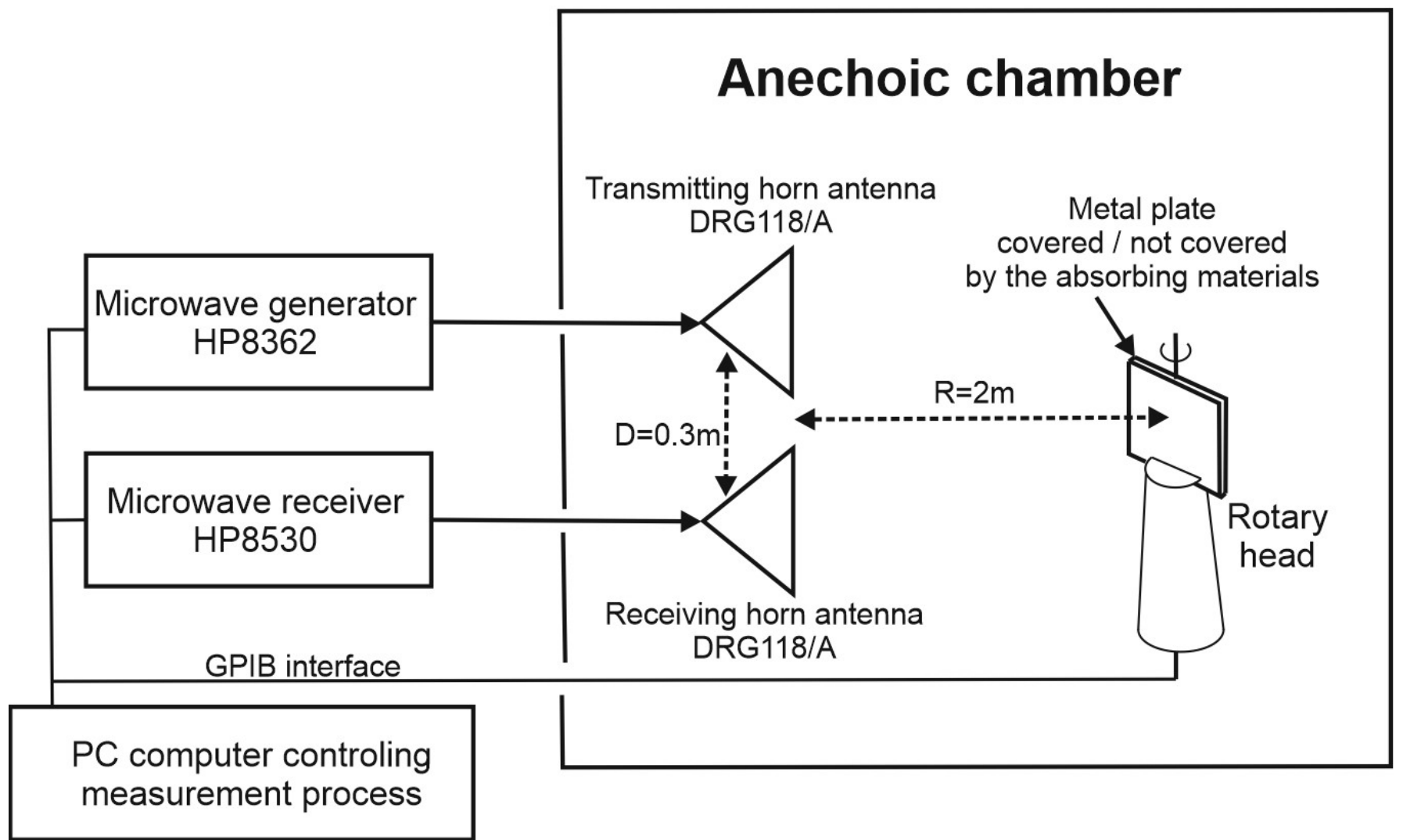

Fig. 3. Block diagram of the laboratory stand for measurements of the absorption of electromagnetic waves

aluminum panels (except the reference plate made of DC01 steel and designated as Sample No. 0), the first is used as a reflector (reference) and the second is coated with absorption material. The panel is fixed on a support, which is positioned in front of the receiving and transmitting antennas. With this methodology it is necessary to make two separate measurements of the signal level reflected by the plate covered with absorption material and without absorption material. The absorption of a broadband absorber constructed as a flat material was successfully evaluated using this methodology in the frequency range of 3.0-11.0 GHz.

It is important in the applied method that the minimum distance of the tested sample from the measurement antennas satisfies the far field zone condition defined as $R>2 D^{2} / \lambda$ (where $D$ is the maximal crosswise dimension of the measurement antenna, and $\lambda$ is the wavelength for the highest measurement frequency). The dimensions of both measurement antennas used during the tests is the same, namely $15.5 \times 10.6 \mathrm{~cm}$. The measurements were performed by maintaining the distances required for all measurement frequencies.

The measurements of the absorption characteristics of tested samples as a function of the testing signal angle of incidence was divided into two stages. The first stage was a reference measurement, in which signal reflected from a reference plate (sample No. 0, which was not covered by the absorption material) was measured. In the sec- ond stage, the measurements of the signal level reflected from the plates covered with absorption materials characterized by the different shapes (spheroidal particles and pyramids) were performed. In the proposed method of measurement, a relative difference between the measured signals in these two stages was the measure of the absorption of the electromagnetic waves.

In this paper, the absorption levels of different absorption elements (spheroids and pyramids) prepared on the base of EMCCO-201 and Kraton materials placed on the Al metal plates were evaluated by comparison to the level of the signal reflected from a reference DC01 plate, not covered with the absorption material. The absorption level is heavily dependent on the angle of the plate surface covered with the absorption material in relation to the transmitting (receiving) antenna aperture and the obtained results allow us to estimate at which angle the maximum absorption value of the tested material can be achieved. The block scheme of the laboratory stand is shown at the Fig. 3.

The testing signal is generated by a microwave generator with a horn transmitting antenna. The signal reflected from the surface covered with the absorption material is measured with a horn reception antenna and a microwave receiver. Measurements are performed in an anechoic chamber covered with suitable absorbers in order to avoid reflections of electromagnetic waves from the floor and walls. In order to control the measur- 
$\mathrm{T}$ a b l e 2. The measuring devices used for measuring the estimation of the absorption level

\begin{tabular}{c|c|c|c}
\hline No & Measurement equipment & Type & Manufacturer \\
\hline 1. & Microwave generator & HP85620 & Hewlett Packard \\
2. & Microwave receiver & HP8530 & Hewlett Packard \\
3. & Anechoic chamber & TEMPEST & TDK Electronics Europe GmbH \\
4. & Horn antenna & DRG118/A & Antenna Research Associates INC. \\
\hline
\end{tabular}

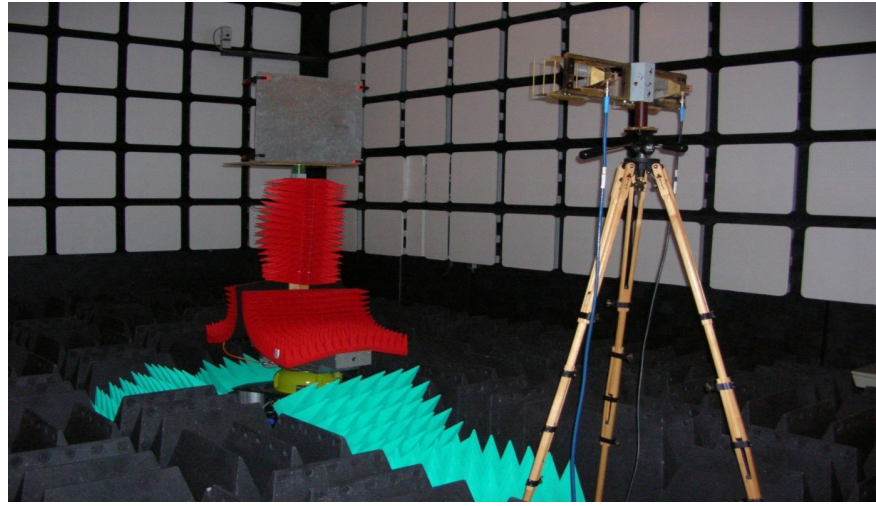

Fig. 4. The measuring station situated inside the anechoic chamber

ing devices, a special computer program was written. As shown in Fig. 4, the applied devices measure the relative power reflected from the Al plate with absorbing sample and without absorbing sample respectively, and then the absorption value is calculated as the difference of measured power values. The measuring station inside the anechoic chamber is presented in Fig. 4 and the description of the applied measuring devices is listed in Table 2.

The laboratory stand applied in these investigations has limits in the dynamic range of measurements. The dynamic range was defined as the difference in decibels between the level of the signal reflected from the metal plate and the level of the signal reflected from the environment (background level). An important factor influencing the dynamic range is the crosstalk between the transmitting antenna and receiving antenna.

\section{RESULTS AND DISCUSSION}

The absorption characteristics of the tested materials as a function of the testing signal angle of incidence and its frequency are presented below. The characteristics are presented in polar coordinates. The results of the measurements correspond with the samples numbered 0,1 , 2, 3 and 4 and were designated in the figures presented below using the following colors:

- metal reference plate - sample No. 0 not covered by absorption material - green color,

- sample No. 1 - red color,

- sample No. 2 - orange color,

- sample No. 3 - blue color,

- sample No. 4 - black color.

The tested materials were illuminated by the transmitting antenna in the range of $0-360^{\circ}$. The phenome- non of absorption reaches a maximum for 0 - parallel arrangement of the transmitting (receiving) antenna's aperture and the plate covered with the tested material. The value of absorption describes the difference between two signals reflected from the tested material and signal reflected from the metal plate.

The absorption characteristics of the examined materials as a function of the testing signal angle of incidence in polar coordinates for samples No. 0, No. 1, No. 2, No. 3. and No. 4 for the frequencies of: $3.0 \mathrm{GHz}, 3.5 \mathrm{GHz}, 4.0$ $\mathrm{GHz}, 4.2 \mathrm{GHz}, 7.0 \mathrm{GHz}, 8.0 \mathrm{GHz}, 9.0 \mathrm{GHz}, 10.0 \mathrm{GHz}$ and $11.0 \mathrm{GHz}$ were examined. The absorption characteristics for frequencies $3.0 \mathrm{GHz}, 7.0 \mathrm{GHz}$ and $11.0 \mathrm{GHz}$ are shown in the Figs. 5-7. According to the fact that the absorption properties of sample No. 0 and sample No. 2 (Al-alloy plate covered with the layer of polymer) are almost similar, the results for sample No. 2 are not presented in this paper. Figures 5, 6 and 7 show the absorption values of the tested absorption materials (samples No. 0, 1, 3 and 4 ) in decibels at $3 \mathrm{GHz}, 7 \mathrm{GHz}$ and $11 \mathrm{GHz}$ frequency, respectively as a function of the rotation angle in the range of the angles from $-90^{\circ}$ to $+90^{\circ}$. In the range of angles from $-90^{\circ}$ to $+90^{\circ}$, a peak at $0^{\circ}$ corresponding to the normal incidence of the radiation on the panel coated by tested absorption material was observed. In the range of $-90^{\circ}$ to $+90^{\circ}$ for sample No. 4 , the highest absorption value of $2.5 \mathrm{~dB}, 5.8 \mathrm{~dB}$ and $4.8 \mathrm{~dB}$, respectively for the following frequencies $3 \mathrm{GHz}, 7 \mathrm{GHz}$ and $11 \mathrm{GHz}$ occurs at $0^{\circ}$, corresponding to the normal incidence of the radiation on the panel coated by the tested absorption material.

In the applied measurement method, the setting up of the reference plate plane, as well as the plate with absorption material, is tremendously important for the accuracy of the measurement results. As can be seen from the presented absorption characteristics, the change of the tested sample location by \pm 10 degrees from the angle of 0 degrees generates a considerable decrease in the signal level by approximately $10 \mathrm{~dB}$.

Figure 8 includes a comparison of the absorptions of samples tested in the function of the selected measured frequencies. The values of absorption for the individual samples for the angle of zero degrees between transmitting and receiving antenna's aperture and the surface covered with the tested material are presented. The angle of zero degrees (parallel arrangement of the transmitting/receiving antenna's aperture and the plate covered with the tested material) was chosen because the phenomenon of absorption reaches a maximum for this value of angle (see Figs. 5, 6 and 7). Samples No. 1 and 


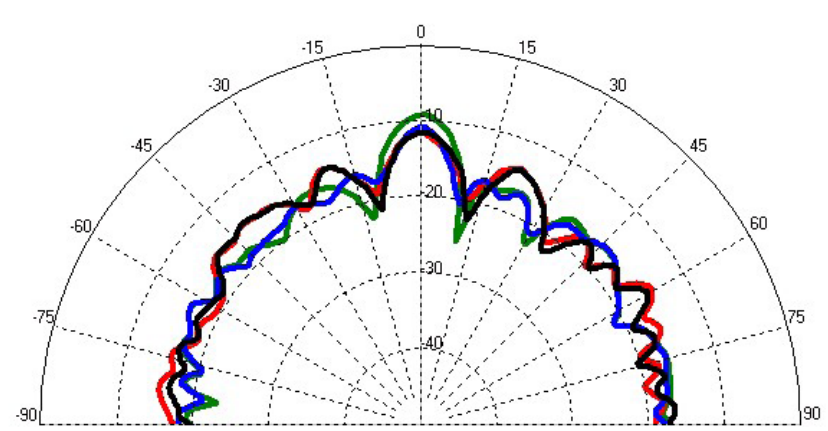

Fig. 5. The absorption characteristics of the examined samples as a function of the testing signal angle of incidence in polar coordinates, frequency $3.0 \mathrm{GHz}$ (radiation pattern)

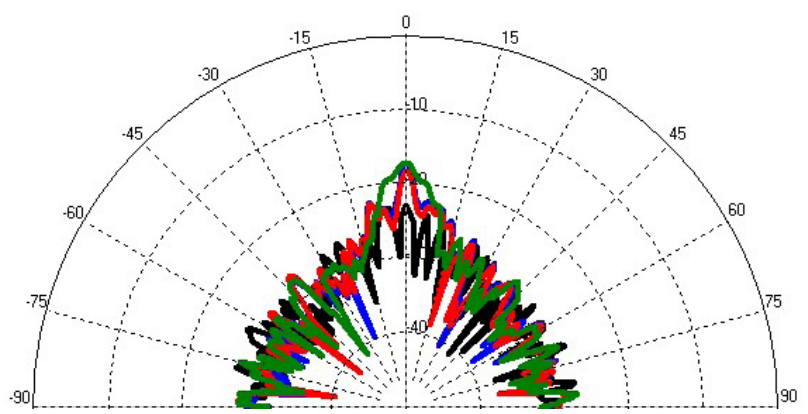

Fig. 6. The absorption characteristics of the examined samples as a function of the testing signal angle of incidence in polar coordinates, frequency $7.0 \mathrm{GHz}$ (radiation pattern)

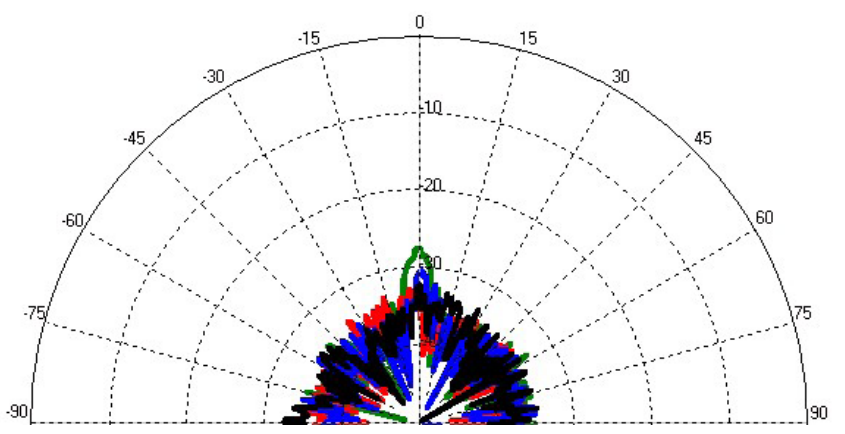

Fig. 7. The absorption characteristics of the examined samples as a function of the testing signal angle of incidence in polar coordinates, frequency $11.0 \mathrm{GHz}$ (radiation pattern)

No. 3 provide good absorption levels above the frequency of $8000 \mathrm{MHz}$, however, sample No. 4 has the highest absorption level within the frequency range 7.0 to 11.0 GHz. Sample No. 4 has good absorption characteristics in a wider frequency range in comparison to samples No. 1 and No. 3. The worst absorption characteristics are shown by sample No. 2. From Fig. 8, it can be concluded that the best absorption of $6 \mathrm{~dB}$ was obtained for sample No. 4 composed of epoxy resin pyramids covered with EMCCO-201 materials for the normal incidence of the radiation on panels coated by tested absorption material. It shows that the absorption is significantly larger when the absorption material has the shape of pyramids.

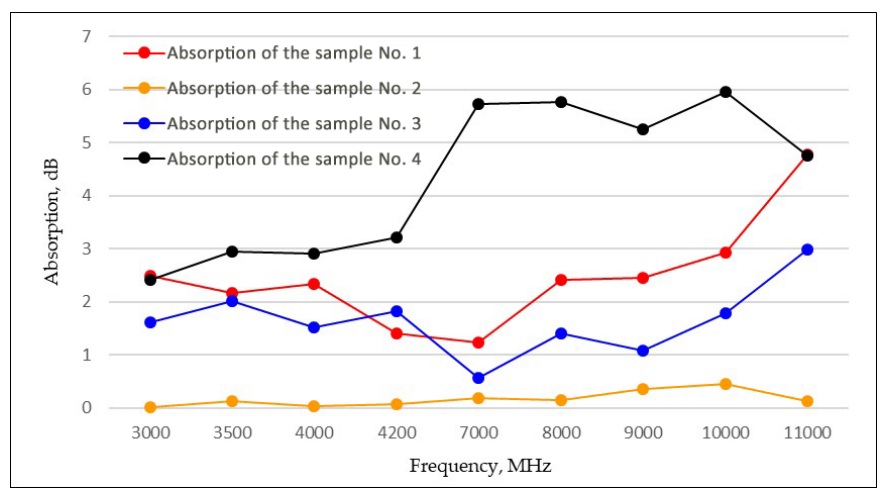

Fig. 8. The values of absorption for the individual samples for the angle of zero degrees between transmitting and receiving antennas aperture and the surface covered with the tested material

\section{CONCLUSIONS}

- The homogeneous mixture of EMCCO-201 material absorption electromagnetic waves characterized by up to 50 vol. \% content in SBS copolymer (Kraton) can be manufactured by extrusion applying the one screw extruder.

- The manufactured materials are characterized by good forming ability and it is possible to plastically deform the composite material EMCCO-201-Kraton to form relatively small spheroidal particles of diameters $1-2 \mathrm{~mm}$ and $3-4 \mathrm{~mm}$.

- It can be concluded that the best absorption of $6 \mathrm{~dB}$ was obtained for sample No. 4 , for the angle of zero degrees between transmitting and receiving antenna's aperture. This sample was composed of epoxy resin pyramids covered with EMCCO-201 materials characterized by a square base of $25 \times 25 \mathrm{~mm}$ and height of $50 \mathrm{~mm}$. Differences in absorption of various samples in the frequency function result from the fact that materials have different absorption characteristics for different testing frequencies. The absorption value for various samples in the applied frequency function depends on the angle of incidence of the electromagnetic wave and the shape of surface of absorption materials. The largest absorption value in the function of the angle of incidence of electromagnetic wave $\left(-90^{\circ}\right.$ to $\left.+90^{\circ}\right)$ is observed for the normal incidence of electromagnetic wave (corresponding to $0^{\circ}$ angle of incidence).

\section{REFERENCES}

[1] Che B.D., Nguyen L.T., Nguyen B.Q. et al.: Macromolecular Research 2014, 11, 1221. http://dx.doi.org/10.1007/s13233-014-2169-8

[2] Zakharychev E.A., Razov E.N., Semchikov Y.U.D. et al.: Bulletin of Materials Science 2016, 2, 451.

[3] Chen Y., Zhang A.L., Ding L. et al.: Composites Part B 2017, 108, 386.

https://doi.org/10.1016/j.compositesb.2016.10.014 
[4] Zhao T., Jin W., Ji W., Yan H. et al.: Journal of Alloys and Compounds 2017, 712, 59. https://doi.org/10.1016/j.jallcom.2017.04.070

[5] Liu P., Ng V.M.H., Yao Z. et al.: Journal of Alloys and Compounds 2017, 701, 841. http://dx.doi.org/10.1016/j.jallcom.2017.01.202

[6] Gholampour M., Movassagh-Alanagh F., Salimkhani H.: Solid State Sciences 2017, 64, 51.

[7] Liu H., Cheng H., Tiana H.: Materials Science and Engineering B 2014, 179, 17. https://doi.org/10.1016/j.solidstatesciences.2016.12.005

[8] Liu Y., Liu X., Wang X.: Journal of Alloys and Compounds 2014, 584, 249. https://doi.org/10.1016/j.jallcom.2013.09.049

[9] Choi J., Jung H.T.: Composite Structures 2015, 122, 166. https://doi.org/10.1016/j.compstruct.2014.11.020

[10] Zhang S.Y., Cao Q.X., Xue Y.R. et al.: Journal of Magnetism and Magnetic Materials 2015, 374, 755.

https://doi.org/10.1016/j.jmmm.2014.08.073

[11] Kumar T., Inayathullah J., Nagarajan V.A. et al.: Bulletin of Materials Science 2016, 1, 279.

http://dx.doi.org/10.1007/s12034-015-1133-3

[12] Wang J., Sun Y., Chen W. et al.: Journal of Applied Physics 2015, 117, 154903.

https://doi.org/10.1063/1.4917486
[13] GB Pat. 2379331 (2000).

[14] Vogt A.A., Kołodziej H.A., Sowa A.E.: "New generation of absorbing materials", The Final Proceedings for 15th Internal Wroclaw Symposium and Exhibition on EMC, Wroclaw, Poland, 27-30 June, 2000, p. 57.

[15] Vogt A.A., Kołodziej H.A., Sowa A.E.: "Hybrid absorber using new absorbing composites", IEEE International Symposium on Electromagnetic Compatibility, Chicago, Illinois, USA 8-12 August, 2005, p. 315.

[16] Brzostek A., Kołodziej H.A., Vogt A.A. et al.: Tworzywa Sztuczne i Chemia 2009, 8, 36.

[17] Nowosielski L., Kubacki R., Przesmycki R.: Advances in Engineering Software 2011, 11, 911.

[18] Rezende M.C., Martin I.M., Faez R.: Revista de Fisica Aplicada e Instrumentacao 2002, 1, 24.

[19] Kubacki R., Nowosielski L., Przesmycki R. et al.: Przeglad Elektrotechniczny 2009, 12, 83.

[20] Nowosielski L., Kubacki R., Przesmycki R.: "WIT Transactions on Modelling and Simulation", WIT Press, USA, 2009, p. 241.

Received 3 II 2020 